\title{
A Comparative Study on the Typical Models of International Innovation-Type Regional Development
}

\author{
Haochen Yang, Haiyuan Zhao, Wei Song \\ The School of Public Affairs, University of Science and Technology of China, Hefei, China \\ Email: 785696509@qq.com
}

How to cite this paper: Yang, H.C., Zhao, H.Y. and Song, W. (2018) A Comparative Study on the Typical Models of International Innovation-Type Regional Development. Open Journal of Social Sciences, 6, 274-288.

https://doi.org/10.4236/jss.2018.63020

Received: February 5, 2018

Accepted: March 27, 2018

Published: March 30, 2018

Copyright $(9) 2018$ by authors and Scientific Research Publishing Inc. This work is licensed under the Creative Commons Attribution International License (CC BY 4.0).

http://creativecommons.org/licenses/by/4.0/

\begin{abstract}
The differences in resource endowment and economic and cultural background in different cities form different types of innovative urban development models gradually. From the perspective of major innovative cities development practices abroad, depending on the different industry, the innovation-oriented city construction can be divided into high-tech innovation-oriented city, traditional industrial manufacturing innovation-oriented city, service industry innovation-oriented city and cultural industries innovation-oriented city (Hospers, 2003). The study selects the strategies and measures of regions of Boston in America, London in UK, Tokyo in Japan, Nordrhein-Westfalen in Germany to analyze, compare, and summarize their experience of development, and accordingly analyzes its enlightenment to the other innovation-type provinces construction of China.
\end{abstract}

\section{Keywords}

Comparative Study, Innovation-Oriented City, Typical Model, Development Experience, Enlightenment

\section{Introduction}

Since the 70s, people have realized that innovation is a systematic process. There was no linear relationship between the elements, but interactive function in the system. Thus, "innovation chain", "innovation circle", "innovation belt", "innovation corridor", "innovation cluster", "innovation system", "national, regional and urban innovation theory" came into being. With the increasing systematization of innovation theory and practice, the innovative subject has gradually ex- 
panded from micro to meso and macro; in particular, the status and role of cities and provinces have been highlighted in the innovation system [1]. In the last 20 years, especially since the 21st century, the economic functions of cities and provinces are changing from traditional industries to high-tech industries, from manufacturing to $\mathrm{R} \& \mathrm{D}$, from production to services and towards innovation centers. Cities, especially central cities, are increasingly becoming carriers and gathering place of innovative resources such as information, technology, brands, knowledge, talent, etc. Innovative cities have made outstanding contributions in supporting the development of related industries and regional economy.

\section{Foreign Innovation-Type Regional Development Model}

There is no concept of province in foreign countries. The research on innovation region is mostly on the city, and the innovation city and the innovation province are only different from the innovation subject. There is no obvious difference between them in the aspects of basic innovation elements, innovation mode, innovation principle, innovation culture, innovation platform and so on, which can be used for reference from each other [2]. The exploration of innovative cities not only promotes the development of regional economic theory and urban science, but also promotes the establishment and improvement of the innovation system of cities, provinces and countries. It is necessary for the construction of innovative provinces in China to study the experience of innovation city construction in foreign major cities.

\subsection{Boston, America: High-Tech Innovation-Type}

High-tech innovation-type cities usually use the high-tech industry as their mainstay, science parks or pioneer parks as the main carriers of innovation, high-level talents and technology in universities as support, and sufficient financing as their guarantee to drive the development of regional economies. As the model of high-tech innovation-type city in the information age, Boston has the first-class level of technology innovation. The four main forces to promote the innovation and development of Boston are the agglomeration of scientific and educational resources and human resources, perfect innovation environment, sufficient venture capital, and deliberate support of the government.

First, the agglomeration of science and education resources and talent resources. From the point of view of science and education resources, Boston has many famous universities, such as Boston University, Harvard University, Massachusetts Institute of Technology, Northeast University and so on. The scientific research strength of these universities is one of the important factors supporting the development of the city. From the point of view of talent resources, teachers, researchers and graduates from these institutions are actively engaged in the innovation construction of the city. So that Boston's corporate research and staff education levels are among the highest in the United States. Meanwhile, Boston also offers a vast array of entrepreneurial and employment oppor- 
tunities for innovative talents. Science and Education, the gathering of Human Resources and the full absorption and utilization of these resources in the city of Boston make the city a unique ability to innovate in science and technology, and it also has the ability to develop the source motivity of high-tech innovative City.

Second, perfect innovation environment. Boston has rich innovation practice experience, innovation culture is deeply rooted in the hearts of the people, the city encourages people to freely think, and encourages people to innovate unremittingly, and create a good cultural atmosphere for Boston. In the meantime, for protecting the rights and interests of innovation, Boston has set up a perfect legal protection system for intellectual property rights, which has eliminated the last worries of innovators, so that the innovation activities are more pure. Finally, Boston's perfect infrastructure, such as the perfect metro network, has facilitated the creation of Boston-based innovation from a hardware environment, creating innovative industrial clusters with Boston characteristics.

Third, adequate venture capital. Innovation can't be won in the beginning, the process is full of failures and challenges, meanwhile, innovation also requires investment in technology, hardware, software, and so on, and therefore usually requires substantial capital support [3]. Boston has a very good financial system, compared with other high-tech innovative cities in the world. Venture investment looks for the potential innovation activities constantly, which gives plenty of venture investment to Boston, these investments provide strong financial support for innovation. The innovative achievements of Boston have also given generous returns on the capital to support innovation, encouraging venture capital to further support innovation. Finally, the virtuous circle of innovation capital is formed, which provides a steady stream of capital support for the innovation and development of the city.

Fourth, the government's deliberate support. Although the main motive force lies in the gathering of science and education talents, injection of venture investment and perfect innovation environment in the process of Boston stepping on the road of innovation-type city development, the role of the government shall not be ignored. While the government's direct support for Boston's innovation is not as straightforward as in other cities, large government orders provide a stable market for Boston's innovation [4]. The market-oriented means of the government indirectly promote the transformation of the city's various innovative achievements and further encourage innovation activities, thus promoting the rapid development of the city (Figure 1).

\subsection{London, Britain: Cultural Industry Innovation}

Cultural industry innovation cities mainly focus on the cultural and artistic fields, and the cultural and creative industries are developed, usually has profound cultural and artistic heritage. London's innovation-type city development model is characterized by its developed cultural and creative industries, which make London to become the world's financial, economic and creative cultural 


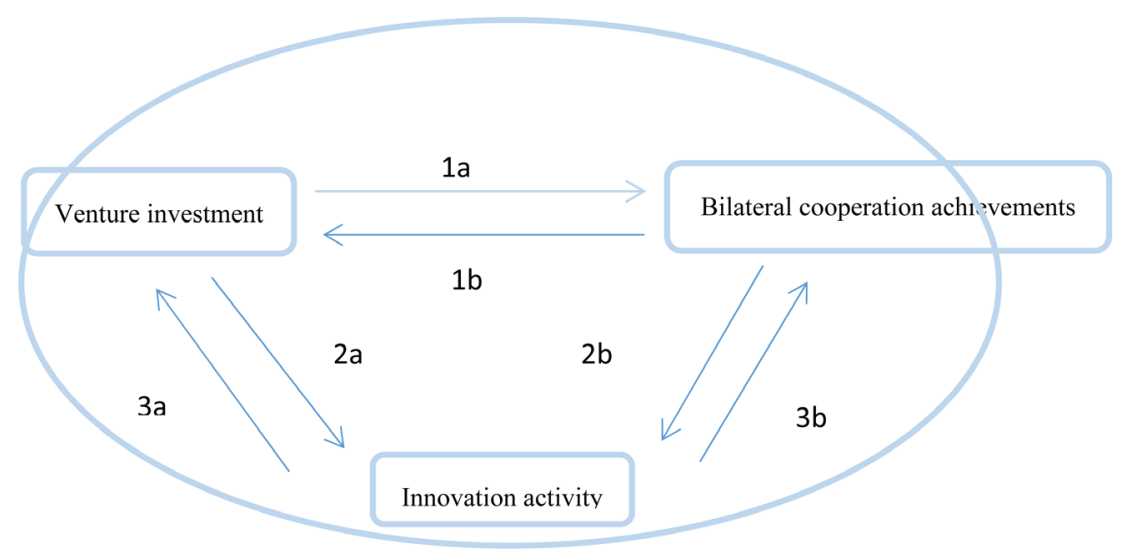

Figure 1. Cycle diagram of innovative venture investment of Boston.

centre. Creative industries are the main pillar of London's economy. In 2014, museums, galleries, libraries, and music, performing and visual arts industries contributed about 5.4 billion pounds to the overall economy of London. The government's preferential policy support for the cultural industry, the innovative system of the three-party cooperation between schools, research institutes and enterprises, and the creation of a cultural atmosphere for urban innovation are the key measures to build an innovation-type city in London (White Paper on the Development of British Cultural Industry in 2016).

First, the government issues corresponding policies and organizes specialized agencies to promote the development of cultural and creative industries. Since 1994, the British Government had attached great importance to the development of its cultural and creative industries, had promoted the work to the level of national policy, and had issued some strategic plan for the development. In 2003, "London: cultural capital-the Mayor's cultural strategy draft" was published in London, which proposed "cultural development strategy is the main way to preserve and strengthen London as the world's premier creative and cultural centre and the goal of building London into a world-class cultural centre" [5]. Meanwhile, the specialized service was supported by setting up a special creative industry committee for the creative and cultural industries. Furthermore, the government also vigorously supported the cultural and creative enterprises by means of improving financial services, financial support and intellectual property protection, which highlighted the guiding role of government forces in the development of London's innovative cities.

Second, develop school-research-enterprise-cooperation innovation system. Apart from the government's emphasis on creative industries, London encourages the development of school-research-enterprise cooperative innovation platform to strengthen regional innovation system for promoting the development of creative culture industry, improving the institutions of higher learning and research the transformation of innovative results, and focus on these regions to radiate the outward to enhance the influence of the region and city, and fur- 
ther promote their own cultural and creative industries. For example, the innovative platform composed of the London Development Bureau, the British Centre for Contemporary Arts, Somethin Else Company, King's College, etc., it not only promotes the steady development of culture and creativity, but also replicates successful experience, and constantly spreads its regional, national and international influence, which plays a positive role in promoting the development and promotion of cultural and creative industries.

Third, create a culture atmosphere of city innovation. London actively creates an innovative cultural atmosphere, citizens' creative life is promoted and supported by education and training, and it also provides a good external environment for the development of cultural and creative industries. In the meantime, London actively carries out various kinds of civil international exchange activities to absorb the outside world advanced culture idea. By strengthening the communication and cooperation with other countries in the field of culture, promoting mutual progress and achieving the popularization and dissemination of the concept of people's innovation. This kind of "national innovation" mode in London, England, has made the endogenous and sustainable development of city innovation [6].

\subsection{Tokyo, Japan: Service Industry Innovation}

The pillar industry in the service industry innovation cities is usually the tertiary industry, and the social comprehensive service ability of the city is very strong. Tokyo's innovation city development model is closer to service industry innovation. The proportion of service industry in GDP is much higher than manufacturing industry (Figure 2, Figure 3), which makes Tokyo to become one of the most economically dynamic cities in Asia. Preferential Policies for New and High Technology, providing financial services for high-tech industries, encouraging cooperation between schools and enterprises, and promoting communication research are became major impetus to support Tokyo, an innovative city with the service industry as its main pillar.

First, enterprises with independent intellectual property rights and strong innovation ability shall be subjected to the preferential fiscal policies. Firstly, innovative enterprises are reduced the equipment tax and equipment purchase

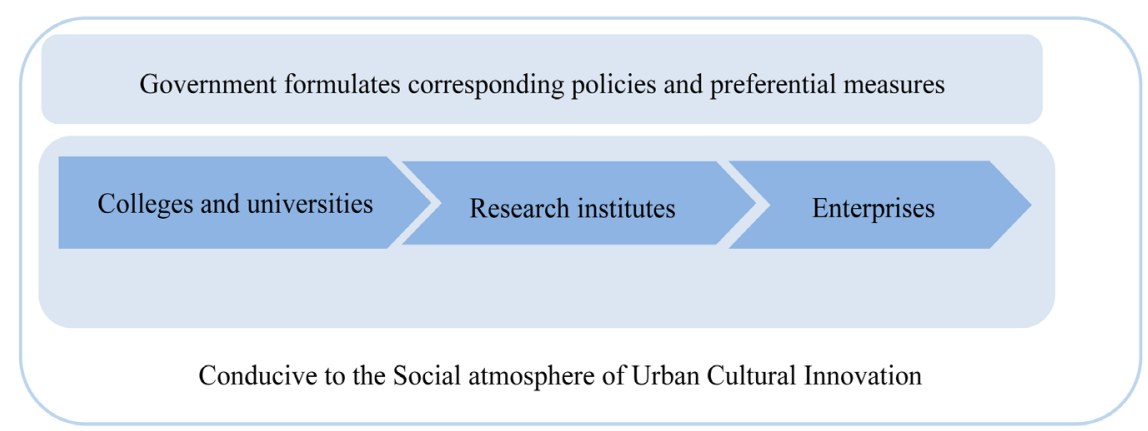

Figure 2. London, British cultural innovation city model. 


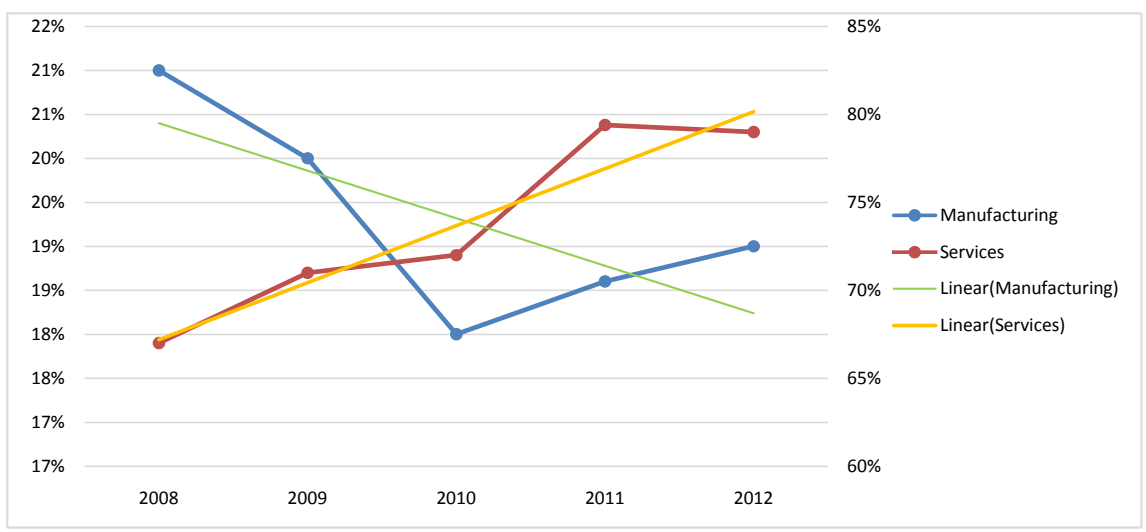

Figure 3. The proportion of Japan's manufacturing and service industries between 2008 to 2012 .

cost; secondly, electronic equipment are allowed to large proportion of special depreciation to promote the upgrading of innovative enterprise equipment. Moreover, information industry is increased loans, and is reduced technology development assets tax, etc. [7]. These preferential policies greatly reduce the innovation costs of innovative enterprises, and encourage and promote the innovation activities of these enterprises with independent innovation ability.

Second, high-tech enterprises are provided perfect financial services. Innovation cannot be separated from the support of funds, in order to promote the innovative activities of high-tech enterprises, Tokyo offers long term, low interest loans, and reduces the cost of innovative credit to these companies. Meanwhile, providing OTC Stock Exchange Market for small and Medium-sized technological Enterprises, and providing these enterprises with low threshold, convenient financing channels, sufficient credit funds and financial capital greatly support the innovative activities of Tokyo high-tech enterprises [8].

Third, encourage cooperation between schools and enterprises. The government encourages industries and universities to establish joint research centers, and provides financial subsidies for joint school enterprise projects; in the meantime, the government gives generous rewards to individuals who make outstanding contributions to innovation activities to encourage enterprises, universities, and individuals in innovation work [9]. The results of the "common" development of university researchers funded by the state can be obtained by individuals with a patent income of $50 \%-80 \%$; the government also encourages industries and universities to set up "joint research centers", which subsidized by the science and technology department.

Fourth, promote communication and research. Tokyo advocates staff exchange among research institutions and encourages to increase the proportion of foreign researchers for absorbing and learning more advanced technology.

\subsection{North Rhine-Westphalia, Germany: Traditional Industrial Manufacturing Innovation}

Traditional industrial manufacturing innovation cities are generally located in 
the surrounding areas of large cities in terms of location, taking the talent and technical resources of the central city as the driving force for development, and at the same time feedbacking the development results to the central city to improve the competitiveness of the city [10]. NRW is short for North Rhine-Westphalia, Germany (Figure 4), once "the center of European industry", Germany's most densely population and prosperous federal state. In 1950s, in order to cope with the trend of world industrial structure adjustment and economic globalization, North Rhine-Westphaliai, relying on the strength of technology, vigorously developed new industries, actively promoted the transformation of traditional industries, and successfully carried out industrial restructuring. It has broken down the single economic structure of mining industry and completed the structural transformation from traditional coal and steel industry to modern industry and service industry with the core of technological innovation.

First, formulate and implement the structural transformation plan with the core of technological progress. In the early 1980s, from the reality of the development of the region, North Rhine-Westphalia has determined the long-term development strategy of transforming from a single coal and iron and steel industry base to a diversified city with economy, and it is not only necessary to strengthen the traditional status of local as a coal and iron and steel industry center, but also to improve the scientific and technological content of the industry, North Rhine-Westphalia focused on the development of high-tech industries represented by biological and genetic technology, as well as services represented by logistics, finance and commerce, to promote the revitalization of the regional economy. In the guidance of planning, in addition to pillar industries of automobile, machinery manufacturing, chemical industry, and energy, North Rhine-Westphalia is also competitive in new media, microelectronics, biology, gene and medical technology and logistics, forming a modern industrial system with the core of technological progress.

Second, strengthen the input intensity in the structural transformation of the economy. Since 1960s, NRW made full use of German government's policy of supporting economic transformation of old industrial base, and made full use of German government's substantial financial subsidies to fund high-technology enterprises and projects in areas such as government procurement, import trade, depreciation policies, government credit, etc., and support traditional industries to implement technological innovation and structural upgrading [11]. Meanwhile, the Ruhr regional structural reconstruction plan was implemented at the end of 1990s by using funds provided by the European Union to promote a series of reconstruction projects and plans, guide enterprises to develop and apply new technologies and techniques, such as backfilling and treatment in various mining areas, construction of comprehensive parks for tourism and vacation, comprehensive consumption and multi-function, etc., promote the timely transformation of traditional industries and enterprises, and achieve the goal of economic restructuring. 


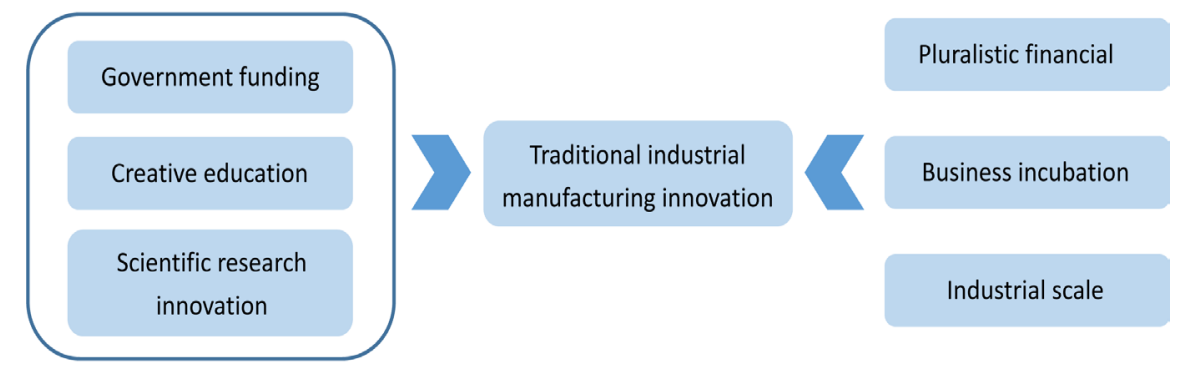

Figure 4. The innovation model of North Rhine-Westphalia, German.

Third, attach great importance to the development of innovation-type small and medium-sized enterprises. In order to encourage the development of innovation-type small and medium-sized enterprises in North Rhine-Westphalia, the government set up a business association, various trade associations, economic promotion associations and overseas liaison organizations to provide professional services for the transformation of small and medium-sized enterprises in the old industrial base, application of new technologies, training of human resources development and expansion of overseas markets, etc., and almost all the cities in the state have set up technology development centers for small and medium-sized enterprises to promote the transformation of scientific and technological innovation and scientific and technological achievements of enterprises and promote the development and expansion of the main body of urban innovation [12].

\section{Development Experience of Innovation-Type Provinces Abroad}

The innovation city construction mechanism of Boston, London, Tokyo, Japan, and North Rhine-Westphalia, Germany, contain good policy environment, support of talents and funds, perfect innovation platform, strong innovation atmosphere and so on. The innovation city construction mechanism of the developed countries (Figure 5) is worthy of our country's reference and study.

\subsection{The Prominent Government Function}

The role of government guidance and protection is one of the core factors to ensure the formation of innovative city construction road. For example, London, is a model of innovative cities developed in the leading role of the government. The government shall give full play to its functions and establish strategic guiding policies on the road of building innovative cities, so as to provide favorable conditions for the policy environment and public services of innovative cities. In the formulation of laws and regulations, the government plays a leading role and forms an important legal protection for the innovation process and interests of each innovation subject. Moreover, the government can also establish a good investment and financing environment for large, medium and small enterprises in innovation-type cities and provide sufficient financial support for innovative 


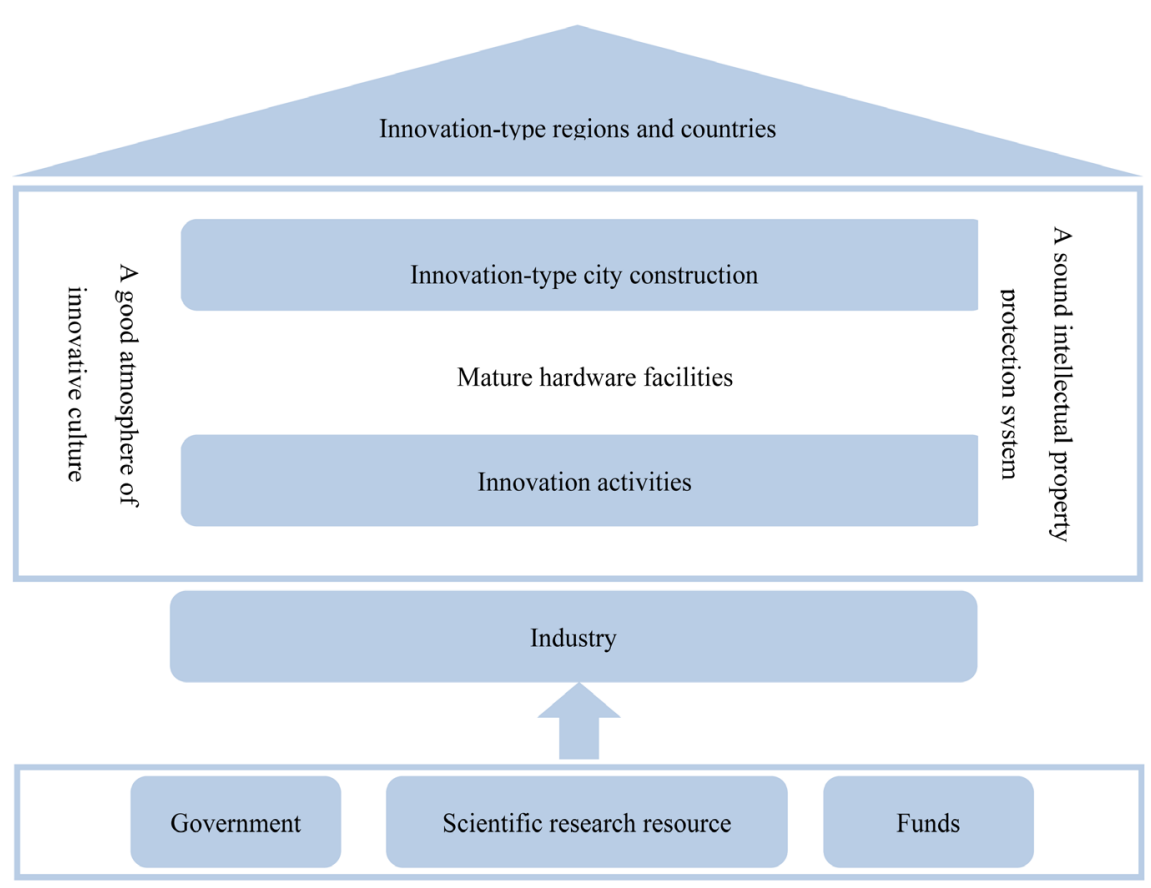

Figure 5. Innovation city construction system in the developed countries.

activities. The governments of Boston, London, Tokyo, Japan, and NorthRhineWestphalia, Germany, have taken many measures to support the construction of innovation-type cities, and have formulated a series of preferential policies. It involves increasing the input of the equipment of the institute, perfecting the public facilities of basic science and technology, increasing the training of innovative talents, and creating a strong atmosphere of innovation, etc.

\subsection{Attach Importance to the Cultivation of Urban Innovation Elements}

It is the common experience of major cities in the world to pay attention to the construction and management of innovative infrastructure, talents and funds, and the major innovation-type cities in the world also focus on cultivating these elements. For example, Boston, attaches great importance to the cultivation of innovative elements in the process of creating a new city. The government has provided large and huge government orders to ensure that Boston's innovative projects have sufficient financial support. In order to cultivate the elements of innovative talents, Boston government makes full use of its advantages in science and education, and makes policies to provide broad opportunities for innovative talents to start their own businesses and find jobs. For protecting the innovative achievements, Boston has also issued a series of laws and regulations on intellectual property protection, and a perfect intellectual property protection system is conducive to the construction of innovative cities. Moreover, the experiences of Japan and Germany also show that the emphasis on the cultivation of factors 
has a significant role in promoting urban innovation.

\subsection{Pay Attention to the Construction of Urban Innovation Platform}

From the practice of the innovative cities construction in foreign major cities, it can be found that the development of major innovative cities emphasizes the consistency, stability and synergy within the innovation system, no matter which kind of development path is chose by the city, science and technology research and development network, technology innovation platform have always played an important role in the construction of innovative cities [13]. The industry-university-research cooperation has innate advantages in integrating scientific and educational resources, technical resources, cultural resources and so on. It is of great significance for creative culture industry in the development of innovative cities to improve the transformation of innovative achievements in colleges and research institutes and to expand the cooperation with enterprises to the level of application. For example, in Boston, the university's research force is one of the key factors supporting the city's development. It is normal for university staff to work part-time in enterprise, which improves the capacity and level of human resources of the overall R \& D team in local enterprises, indirectly contributes to the development of innovative cities. London encourages the development of innovative platforms based on the model of industry-university-research cooperation, and promotes the innovation influence and core competitiveness of regions and cities by focusing on the region where the innovation results are located. In Japan, most of the capital demand for academic research comes from enterprises, which provide guarantee for the cooperation of industry-university-research through financial support [14].

\subsection{Pay Attention to the Construction of Urban Innovative Culture}

The humanistic environment and cultural environment play an important role in promoting the construction of innovation-type cities. The development experience of typical innovative cities in developed countries is inseparable from good innovation atmosphere. Innovation atmosphere seems to have little direct effect on innovation activities, but it can directly reflect the quality of citizens, humanistic care and urban vitality in a city. The innovation environment is the essential element to breed the city innovation atmosphere. A good educational environment and rich practical opportunities enable everyone to enjoy good culture edification, and these cultures eventually develop into innovative ideas rooted in the minds of citizens. People can better accept the influx of various cultures to build an open mind. In the process of long-term creative culture industry development, London has formed its own characteristic culture type and atmosphere, and it also effectively puts cultural innovation thinking into all aspects of civic life, and provides a "national innovation" market atmosphere for the development of its cultural and creative industries (Table 1). 
Table 1. An analysis table for the development of the major innovative cities in foreign countries.

\begin{tabular}{|c|c|c|c|c|}
\hline & Boston America & London Britain & Tokyo Japan & $\begin{array}{c}\text { North Rhine-Westphalia } \\
\text { Germany }\end{array}$ \\
\hline 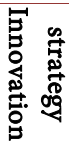 & $\begin{array}{l}\text { High-tech technological } \\
\text { innovation strategy }\end{array}$ & $\begin{array}{l}\text { Innovation strategy of } \\
\text { cultural industry }\end{array}$ & Service industry innovation strategy & $\begin{array}{l}\text { Innovation strategy of traditional } \\
\text { industrial manufacturing industry }\end{array}$ \\
\hline 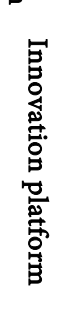 & $\begin{array}{l}\text { 1. Industry-university-research } \\
\text { cooperation platform } \\
\text { 2. School enterprise joint } \\
\text { laboratory } \\
\text { (FabLab laboratory, etc.) }\end{array}$ & $\begin{array}{l}\text { 1. To develop the } \\
\text { industry- } \\
\text { university-research } \\
\text { cooperative innovation } \\
\text { system } \\
2 . \text { To set up a special } \\
\text { creative industry } \\
\text { committee }\end{array}$ & $\begin{array}{l}\text { 1. Industrial circle and universities } \\
\text { are established cooperative research } \\
\text { center } \\
\text { 2. OTC Stock Exchange Market is } \\
\text { provided for small and } \\
\text { medium-sized technological } \\
\text { enterprises }\end{array}$ & $\begin{array}{l}\text { 1. Chamber of Commerce and } \\
\text { Industry, various trade associations, } \\
\text { economic promotion associations } \\
\text { and liaison agencies stationed } \\
\text { abroad, etc. } \\
\text { 2. Technology Development Center } \\
\text { is facing to small and Medium-sized } \\
\text { Enterprises }\end{array}$ \\
\hline 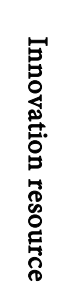 & $\begin{array}{l}\text { The agglomeration of scientific and } \\
\text { educational resources and human } \\
\text { resources; adequate } \\
\text { investment in venture capital; the } \\
\text { Government's deliberate support; } \\
\text { perfect innovation environment; } \\
\text { rich innovative practical } \\
\text { experience; perfect infrastructure }\end{array}$ & $\begin{array}{l}\text { The remarkable regional } \\
\text { advantage; creative cultural } \\
\text { resources; cultural } \\
\text { innovation talent } \\
\text { gathering; strong cultural } \\
\text { heritage; international } \\
\text { communication and } \\
\text { influence }\end{array}$ & $\begin{array}{l}\text { Adequate credit and financial } \\
\text { capital; the remarkable regional } \\
\text { advantage; rapid growth of financial } \\
\text { industry; international exchanges; } \\
\text { innovative talent agglomeration }\end{array}$ & $\begin{array}{l}\text { The remarkable regional advantage; } \\
\text { the perfect infrastructure of the old } \\
\text { industrial base; rapid growth of } \\
\text { financial industry; strong cultural } \\
\text { heritage; international } \\
\text { communication and influence }\end{array}$ \\
\hline 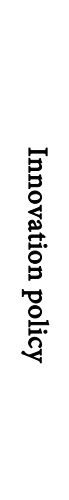 & $\begin{array}{l}\text { 1. A set of perfect intellectual } \\
\text { property legal protection system is } \\
\text { set up } \\
\text { 2. The government procurement } \\
\text { provides large order support } \\
\text { 3. Providing financial support for } \\
\text { small and medium-sized } \\
\text { enterprises' innovation } \\
\text { 4. Convenient conditions of } \\
\text { financial and approval for high-tech } \\
\text { industries }\end{array}$ & $\begin{array}{l}\text { 1. The work is promoted to } \\
\text { national policy level, and a } \\
\text { strategic plan for the } \\
\text { development of cadres is } \\
\text { issued one after another } \\
\text { 2. Perfect intellectual } \\
\text { property protection system }\end{array}$ & $\begin{array}{l}\text { 1. Enterprises with independent } \\
\text { intellectual property rights and } \\
\text { strong innovation ability is } \\
\text { implemented preferential fiscal policy } \\
\text { 2. Joint school and enterprise } \\
\text { project is provided financial } \\
\text { subsidies; } \\
\text { 3. The government offers generous } \\
\text { rewards to individuals who make } \\
\text { outstanding contributions to } \\
\text { innovative activities }\end{array}$ & $\begin{array}{l}\text { 1. fiscal subsidies } \\
\text { 2. Enterprise and project support } \\
\text { with high technology content are } \\
\text { given in the areas of government } \\
\text { yprocurement, import trade, } \\
\text { depreciation policy, and } \\
\text { government credit, etc. } \\
\text { 3. Technological Innovation and } \\
\text { structural upgrading of traditional } \\
\text { Industries are supported } \\
4 \text {. The EU provides some funds to } \\
\text { guide innovation and build an } \\
\text { innovation park }\end{array}$ \\
\hline 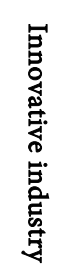 & $\begin{array}{l}\text { Innovative industrial clusters and } \\
\text { high-tech industries } \\
\text { (nanometers, communications, etc.) }\end{array}$ & $\begin{array}{l}\text { The development of } \\
\text { cultural and creative } \\
\text { industries and develop a } \\
\text { cooperative innovation } \\
\text { ) system between schools, } \\
\text { research and enterprises } \\
\text { are promoted }\end{array}$ & $\begin{array}{l}\text { To encourage innovative activities } \\
\text { with independent innovation } \\
\text { capability. Vigorously develop new } \\
\text { and high technology, as well as the } \\
\text { service industry }\end{array}$ & $\begin{array}{l}\text { A modern industrial system with } \\
\text { the core technological progress has } \\
\text { been formed. }\end{array}$ \\
\hline 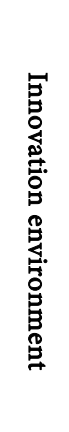 & $\begin{array}{l}\text { 1. Innovative culture is deeply } \\
\text { rooted in people's hearts } \\
\text { 2. Openness and inclusiveness, } \\
\text { cultural exchange } \\
\text { 3. Good policy support }\end{array}$ & $\begin{array}{l}\text { 1. To create innovative } \\
\text { cultural atmosphere and } \\
\text { implant innovation into } \\
\text { citizen's life } \\
2 . \text { To actively carry out } \\
\text { various kinds of civil } \\
\text { international exchange } \\
\text { activities and learn to } \\
\text { absorb the advanced } \\
\text { cultural idea outside the } \\
\text { outside world }\end{array}$ & $\begin{array}{l}\text { 1. Attach importance to } \\
\text { communication research; } \\
\text { 2. Good policy support } \\
\text { 3. Adequate credit capital }\end{array}$ & $\begin{array}{l}\text { 1. Attach great importance to the } \\
\text { development of innovative small } \\
\text { and medium-sized enterprises } \\
\text { 2. Characteristic park construction } \\
\text { 3. Good policy support }\end{array}$ \\
\hline
\end{tabular}

(Note: this table compare to the construction of innovative cities in developed countries by six dimensions of innovation strategy, innovation platform, innovation resources, innovation policy, innovation industry and innovation environment in considering the macro factors affecting the construction of innovative cities. Data source: Collect policies and measures related to the policy papers from the major innovative cities government's official website in foreign countries.) 


\section{Inspiration to the Innovation-Type Provinces Construction of China}

The above analysis of the innovation-type cities of Boston, London, Tokyo, and North Rhine-Westphalia shows that there are significant differences in innovation patterns among different cities in different countries, but the mechanism of innovation development is roughly the same. Foreign innovative city construction generally attaches importance to the role of government, cultivation of innovation elements, construction of innovation platform, and creation of innovative culture, etc. China has more than 2000 years of cultural heritage. In recent years, the socio-economic development has been rapid, and the level of science and technology education has been continuously improved. Not only a large number of internationally-renowned innovative companies have emerged, but also the scientific and technological talents cultivated by universities have played an important role. We should seize opportunities, learn from the experience of foreign development of innovative cities, combine the national conditions of our country to build innovation-type provinces with local characteristics, and then actively build innovative countries.

\subsection{Strengthening Government Guidance and Support}

The government plays an important role in promoting the formation of innovative provincial system. Different governance ideas and inclined areas will directly affect the future development of provinces. The provincial government shall take note of the important role of the government in promoting the construction of innovative provinces, and formulate the innovative urban development strategy and planning design with Anhui characteristics for the specific situation of Anhui Province. In the aspect of laws and regulations, it is necessary to introduce the corresponding laws and regulations to guarantee the innovation achievements, standardize the operation of the innovation platform, and perfect the legal system which is the powerful guarantee for the construction of the innovative provinces in Anhui Province. Various business plans with the core development of high and new technology are formulated to create business opportunities for industry-university-research cooperation. Anhui government needs to play its own role to create a good cultural atmosphere for the province's innovation and development, increase investment in scientific and technological infrastructure, increase support for related industries, and attach importance to the development of education. Anhui government shall focus on the leading role in the innovative construction, and promote the innovation construction of the province through perfecting financial services, financial support and establishing good intellectual property rights protection and so on.

\subsection{Pay Attention to the Cultivation of Innovation Elements in Anhui Province}

Anhui Province shall attach importance to the cultivation of urban innovation 
elements, such as innovation infrastructure, innovative talents, innovative funds and so on. And Anhui Province shall increase investment in science and technology infrastructure, such as libraries and technology laboratories, plan and build a batch scientific and technological infrastructure, actively build science and technology public service facilities of large scientific instruments and equipment, scientific and technological literature information, industry common technology, intellectual property, and build a network of innovative infrastructure. A strong atmosphere of "respecting knowledge, respecting talent and respecting creation" should be formed to increase the selection, cultivation and support of scientific and technological innovation talents, actively introduce Science and Technology Innovation talents needed in Anhui Province, carry out a variety of forms of scientific and technological personnel exchange activities, and build an independent innovation ladder with strong scientific and technological innovation ability, reasonable structure and flexible organization. The financial support for technological innovation in Anhui Province shall be increased to integrate and use all kinds of funds for technology innovation and high-tech industry development fund, encourage enterprises to increase investment in research and development, promote the financial sector to increase support for technological innovation, and actively introduce venture capital, strengthen the combination of venture capital and technological research and development, and improve the conversion rate of scientific research results [15]. Anhui province shall improve the technology trading market, build an international platform for the exchange of scientific and technological achievements, form an open and shared mechanism, promote the flow of knowledge, the diffusion of technology and the effective allocation of scientific and technological resources, and open up channels for the exchange of scientific and technological achievements, and enhance the ability to introduce and transform scientific and technological achievements [16].

\subsection{Supporting the Construction of a Platform for Industry-University-Research Cooperation}

Anhui Province shall focus on constructing "three platforms" for Scientific and technological Innovation of the Government, Enterprises and Scientific Research Institutes on the basis of excavating its own scientific and technological innovation ability, that is, to give play to the role of the government in promoting scientific and technological innovation, perfect the service system of scientific and technological innovation, promote the sharing of scientific and technological resources, and build a government innovation platform that integrates technology research and development, hatching, and industrial achievements into one; give full play to the role of independent innovation in enterprises and strengthen the construction of independent innovation ability of enterprises, especially key enterprises and small and medium enterprises, cultivate a batch core technologies with independent intellectual property rights, and promote the in- 
dustrialization of high-tech achievements and the high-tech innovation platform of traditional industries [17]. Finally, by promoting the linkage development of innovation platform among government, enterprises and scientific research institutions, Anhui Province shall carry out cross-sectoral and cross-domain technical exchange and cooperation at home and abroad, promote the digestion, absorption and innovation of innovative ideas and technologies, establish and perfect the Innovation system of Anhui Province based on the market orientation and industry-university-research cooperation, strengthen the technological competitiveness of Anhui Province and create a competitive innovative province.

\subsection{Creating a Cultural Atmosphere of Mass Innovation}

The innovation-oriented city construction needs a good cultural atmosphere of innovation. The construction practice of major innovative cities in the world shows that innovation spirit and culture are the source and important guarantee of the development of innovative cities, and are the spiritual conditions to attract people to carry out innovative activities [18]. It is also the motive force that stimulates the people to participate in the innovation activity. In the construction of innovative provinces, Anhui Province shall actively cultivate the spirit of innovation. To create a culture of innovation that advocates science, encourages invention, tolerates failure, and advocates a culture of innovation that dares to take risks, innovate, pursue success, tolerate failures, be open and tolerant, and advocate competition, promote widespread acceptance by the public of outstanding foreign cultures and advanced ideas, and absorb the world's advanced culture with a pluralistic and open mind in the province, It takes part in the international innovation exchange with the attitude of tolerance and self-confidence, multiple openness, forms the innovation idea, and injects long-term vitality into the innovation activities of Anhui Province. Meanwhile, Anhui Province shall also further strengthen the concept of intellectual property, enhance the awareness of intellectual property rights of urban people, enterprises and governments, and form an innovative culture conducive to promoting independent innovation and possessing independent intellectual property rights in Anhui Province. The protection of intellectual property rights is became the common action of different subjects.

\section{Acknowledgements}

The research is financed by the Philosophy and Social Science Foundation of Anhui under Grant Nos. AHSKZ2016D07t, and he Natural Science Foundation of Anhui under Grant Nos. 1508085QG143.

\section{References}

[1] Duan, J., Zhang, Z.L. and Long, H. (2016) Innovation-Oriented City Development Patterns Analysis and Innobation Ability Evaluation-A Case Study of Shenzhen. 
No. $1,58-63$.

[2] Lan, X.J. and Chen, J. (2015) Research on the Development Model of Innovation-Oriented City. Journal of Chongqing Second Normal University, No. 5, 24-28.

[3] Wu, S.C. (2014) Research on R \& D Model and Innovation Performance of Innovation-Oriented City Enterprises. Management of Scientific Research, No. 1, 33-40.

[4] Peng, J.L. (2013) Research on the Mode of Science Popularization in Innovation-Oriented City. Guangxi University, Wuzhou, 96.

[5] Bo, J.Z., Cao, J. and Si, F.L. (2013) Analysis on the Construction Mode of Innovation-Oriented City. Commercial Age, No. 33, 20-21.

[6] Xu, A.P. (2013) Study on the Evolution Process of Innovation-Oriented Development Model-Based on Niche Theory Perspective. Development and Research, No. 6, 30-35.

[7] Jiang, Y.T. and Zheng, H.T. (2013) A Comparative Study on the Way and Mode of Innovation-Oriented City Construction-Take Guangzhou and Shenzhen as an Example. Technological Management Research, No. 14, 24-30.

[8] Xu, A.P. (2013) Research on the Development Mode and Innovation-Oriented City Way. Hebei University of Technology, Tianjin, 200.

[9] You, J.X., et al. (2011) Analysis on the Construction Mode of Innovation-Oriented City-Take Shanghai and Shenzhen as Examples. China Soft Science, No. 7, 82-92.

[10] Jiang, X.L. (2010) Research on the Domestic Practice and Basic Mode of Innovation-Oriented City Construction. China Urban Economy, No. 10, 36+38.

[11] Hu, T. and Liu, Q. (2010) Construction Practice and Mode of Innovation-Oriented City. Journal of Administrative Colleges in Other Provinces and Cities of China, No. 4, 57-61.

[12] Shen, L. and Wang, R. (2009) A Summary of the Types and Patterns of Conditions for the Construction of Innovation-Oriented City. Market Modernization, No. 14, 325-326.

[13] Chen, Z. (2009) The Enterprise Path of Innovation-Oriented City Construction-Analysis on the Independent Innovation Mode of Shenzhen Enterprises with Competitive Advantage. Journal of Nantong University (Social Sciences Edition), No. 4, 108-115.

[14] Lu, L., et al. (2008) Research on the Mode of Promoting International Scientific and Technological Cooperation in Innovation-Oriented City. Management of Scientific Research, S1, 75-79.

[15] Gu, S. and Ying, K. (2008) Discussion on Construction Fund Allocation Mode in the Background of the Innovation-Oriented City. Zhejiang Financial, No. 10, 33-34.

[16] He, Y. (2007) An Analysis of the Elements and Models of the Innovation-Oriented City. Market Modernization, No. 8, 228-229.

[17] Zhang, G. and Lin, C. (2006) International Comparison of the Innovation-Oriented City Construction Models-Take London, Boston, Singapore as an Example. The 2nd China Symposium on Science and Technology Policy and Management and International Forum on Science and Technology Metrology, Dalian, 8.

[18] Yang, D., Zhao, L. and Yan, L. (2006) Innovation-Oriented City: Conceptual Model and Development Model. Science and Technology Management, No. 8, 97-101. 